\title{
Seroepidemiology of Toxoplasma gondii in domestic cattle, sheep, goats and pigs from São Tomé and Príncipe
}

\author{
Soroepidemiologia de Toxoplasma gondii em bovinos, ovinos, caprinos \\ e suínos domésticos de São Tomé e Príncipe \\ Daniela Cruz Pereira ${ }^{1}$, Jitender Pradash Dubey², Alfredo da Mata ${ }^{3}$, Helda Neto ${ }^{3,4}$, \\ Luís Cardoso ${ }^{1,5} *$ (D), Ana Patrícia Lopes ${ }^{1,5}$ \\ ${ }^{1}$ Departamento de Ciências Veterinárias, Escola de Ciências Agrárias e Veterinárias, Universidade de Trás-os-Montes e \\ Alto Douro - UTAD, Vila Real, Portugal \\ ${ }^{2}$ Animal Parasitic Diseases Laboratory, Beltsville Agricultural Research Center, Agricultural Research Service, United States \\ Department of Agriculture, Beltsville, MD, United States of America \\ ${ }^{3}$ Direcção da Pecuária, Ministério de Agricultura, Pescas e Desenvolvimento Rural, São Tomé, São Tomé e Príncipe \\ ${ }^{4}$ Laboratório Central de Diagnóstico Veterinário de São Tomé, São Tomé, São Tomé e Príncipe \\ ${ }^{5}$ Centro de Ciência Animal e Veterinária - CECAV, Universidade de Trás-os-Montes e Alto - UTAD, Vila Real, Portugal
}

How to cite: Pereira DC, Dubey JP, Mata A, Neto H, Cardoso L, Lopes AP. Seroepidemiology of Toxoplasma gondii in domestic cattle, sheep, goats and pigs from São Tomé and Príncipe. Braz J Vet Parasitol 2020; 29(1): e014819. https://doi.org/10.1590/S1984-29612019101

\begin{abstract}
Despite the global importance of the zoonotic parasite Toxoplasma gondii, little is known regarding its infection in the Democratic Republic of São Tomé and Príncipe (DRSTP). This is the first report of antibodies to $T$. gondii in cattle, sheep, goats and pigs from the DRSTP. Antibodies were assessed by the modified agglutination test (MAT), with a cut-off titer of 100 for cattle and 20 for sheep, goats and pigs. The present study revealed an overall seroprevalence of 55.8\%; $27.1 \%$ in 48 cattle, $68.4 \%$ in 98 sheep, $70.1 \%$ in 97 goats and $43.7 \%$ in 103 pigs. The south geographical area for cattle, the central area for sheep, and adult age and living in the central region for goats were found to be risk factors for seropositivity to $T$. gondii. These results support the scenario of a considerable presence of sporulated oocysts as well as of infected intermediate hosts in the local environment. Consumption of raw or undercooked meat should be considered as an important potential source of infection for animals and humans in the DRSTP.
\end{abstract}

Keywords: Livestock, modified agglutination test, seroprevalence, toxoplasmosis.

\section{Resumo}

Apesar da importância global do parasita zoonótico Toxoplasma gondii, pouco se conhece sobre sua infecção na República Democrática de São Tomé e Príncipe (RDSTP). Esse é o primeiro relato de anticorpos para $T$. gondii em bovinos, ovinos, caprinos e suínos da RDSTP. Os anticorpos foram pesquisados pelo teste de aglutinação direta modificada (TADM), com um título de corte de 100 para bovinos e de 20 para ovinos, caprinos e suínos. O presente estudo revelou uma soroprevalência global de 55,8\%: 27,1\% em 48 bovinos, 68,4\% em 98 ovinos, 70,1\% em 97 caprinos e 43,7\% em 103 suínos. A área geográfica sul para os bovinos, a área central para os ovinos, bem como a idade adulta e a região central para os caprinos foram considerados fatores de risco para soropositividade a $T$. gondii. Esses resultados suportam o cenário de uma considerável presença de oocistos esporulados, bem como de hospedeiros intermediários infectados no ambiente local. 
O consumo de carne crua ou mal passada deve ser considerado como uma importante fonte potencial de infecção para animais e seres humanos na RDSTP.

Palavras-chave: Pecuária, teste de aglutinação direta modificada, soroprevalência, toxoplasmose.

\section{Introduction}

Toxoplasma gondii, a protozoan parasite well known in homeothermic animals, is estimated to infect one-third of the world's human population (Dubey, 2010; Halonen \& Weiss, 2013). The seroprevalence of $T$. gondii varies according to the lifestyle of definitive hosts, such as the domestic cat and other felines, and intermediated hosts, including people (Defeo et al., 2002).

Among food animals, T. gondii has been found more prevalent in sheep, goats and pigs, than in cattle. This parasite is a major cause of infectious abortion and neonatal mortality in sheep, as well as in goats (Dubey, 2010). Toxoplasma gondii also causes serious illness in congenitally infected children. In addition, it is a pathogenic agent with tropism to the central nervous system, which can cause encephalitis with severe sequelae and systemic infections in immunodepressed humans (Halonen \& Weiss, 2013).

Despite its global importance, little is known regarding $T$. gondii in the Democratic Republic of São Tomé and Príncipe (DRSTP). Previous reports have documented prevalence of $T$. gondii antibodies in children aged $1-5$ years (21.5\%), in primary school students (63.1\%) and pregnant women (75.2\%) in the DRSTP (Fan et al., 2006, 2012; Hung et al., 2007). Due to the shared environment of several animal species in the DRSTP, it is essential to complement and update the epidemiological status of this protozoal infection in definitive and intermediated hosts (Tenter et al., 2000).

The present study aimed at estimating the seroprevalence of $T$. gondii in cattle, sheep, goats and pigs from São Tomé, in the DRSTP, as well as at assessing the main risk factors associated with the presence of specific antibodies.

\section{Materials and Methods}

\section{Geographical area of the study}

The present study was conducted on the island of São Tomé, which is part of the DRSTP, an insular state located near the Equator line in the Gulf of Guinea and distancing $300 \mathrm{~km}$ from the West African coast (Figure 1). This archipelago consists of two main islands, São Tomé and Príncipe, and some adjacent islets, all totalizing an area of $1001 \mathrm{~km}^{2}$, which makes the DRSTP one of the smallest African countries, second only to the Seychelles. According to the United Nations Population Fund (UNFPA), the country had 200,000 inhabitants in 2017 (INE, 2017). 


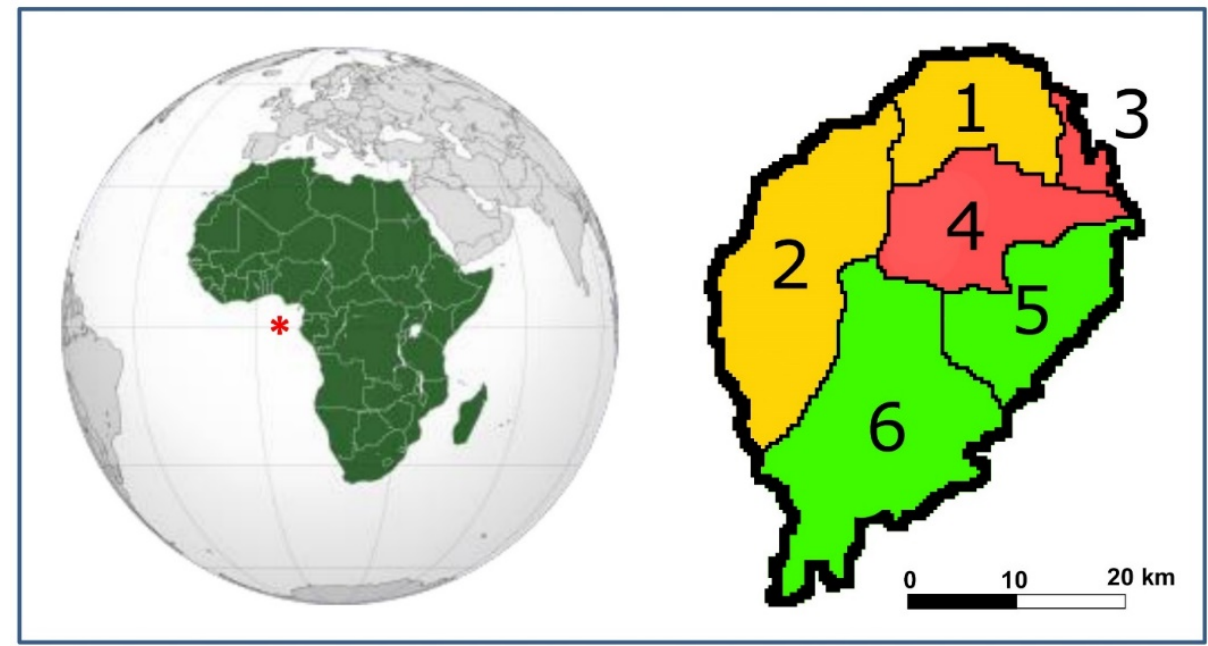

Figure 1. Location of the Democratic Republic of São Tomé and Príncipe (asterisk) in Africa. Geographical areas of São Tomé island: north (yellow), center (red), south (green); and districts: Lobata (1), Lembá (2), São Tomé (3), Mé-Zóxi (4), Cantagalo (5), Caué (6). Source: Images adapted from Wikipedia (2017).

The climate is tropical, hot and humid throughout the year, with average temperatures of around $27^{\circ} \mathrm{C}$ and little daily variation. Rain fall is more abundant in the southern part of São Tomé island and scarcer in the northern part of the same island, where the capital city (São Tomé) is located. The population consists mainly of descendants of native West African individuals miscegenated with European immigrants. One third of the inhabitants live in São Tomé city and its outskirts, but many people still live in dispersed settlements. More than $40 \%$ of the population is less than 15 years of age, and another $25 \%$ is younger than 30 . Life expectancy in the early 21 st century was more than 65 years of age, a relatively high value for an African country and close to the world average. The main crop of São Tomé is cocoa, representing about 95\% of agricultural exports. Other export crops include copra, palm kernels and coffee. The DRSTP is one the most stable and democratic countries of Africa (Costa et al., 2014; INE, 2017).

Cats, both domestic and stray, are abundant on São Tomé island and due to the tropical climatic conditions, suitable for sporulation of $T$. gondii oocysts, it is likely that exposure to sporulated oocysts is one of the most important factors associated with seropositivity to the protozoan in people (Fan et al., 2006; Hung et al., 2007). Furthermore, almost $80 \%$ of primary schoolchildren (Fan et al., 2012) and around $85 \%$ of pregnant women (Hung et al., 2007) drink unboiled water, which may be contaminated with oocysts.

\section{Animals and samples}

From August 2017 to October 2017, blood samples were obtained from 346 domestic animals, comprising cattle $(n=48)$, sheep $(n=98)$, goats $(n=97)$ and pigs $(n=103)$, from the northern (Lembá and Lobata districts), central (Água Grande and Mé-Zoxi) and southern (Cantagalo and Caué) geographical areas of São Tomé island (Figure 1). All sampled animals were raised in São Tomé and were intended for human consumption.

In addition to the geographical characterization, data also included gender (female or male) and age (juvenile or adult) for all species tested and breed (mixed or defined) for cattle and pigs. Animals were classified as adult if they were $\geq 18$ months for cattle, $\geq 12$ months for sheep, $\geq 12$ months for goats and $\geq 8$ months for pigs. Defined breeds 
comprised Nellore for cattle and Large White for pigs. All cattle, sheep, goats and pigs sampled came from farms where cats were present.

Blood was collected by venipuncture of manually restrained cattle, sheep and goats on farms and from pigs bled at the Central Slaughterhouse of São Tomé. After centrifugation of clotted blood, sera were separated and stored at $-20^{\circ} \mathrm{C}$ until serological testing at the Laboratory of Parasitology of the University of Trás-os-Montes e Alto Douro (UTAD).

Owners provided their informed consent for the inclusion of their animals in the study, which had previously been approved by the Directorate for Livestock of the Ministry of Agriculture, Fisheries and Rural Development of the DRSTP.

\section{Serological testing}

Serum samples were tested for immunoglobulin $G$ antibodies to $T$. gondii by the modified agglutination test (MAT) using a commercial kit (Toxo-Screen DA®, bioMérieux, Lyon, France). Sera from sheep, goats and pigs were diluted at 1:20, 1:400, 1:1600 and 1:6400; and bovine sera at 1:100, 1:400, 1:1600 and 1:6400. Positive and negative controls provided with the kit were included on each testing plate. The results obtained with the MAT were expressed as an antibody titer, i.e. the reciprocal of the highest dilution at which agglutination (at least half the well diameter) is still visible after $18 \mathrm{~h}$ incubation at room temperature. The commercial MAT is the same as used by others (Dubey \& Desmonts, 1987).

Cut-off titers of 20 for sheep, goats (Sousa et al., 2009; Lopes et al., 2013) and pigs (Dubey et al., 1995; Lopes et al., 2013) and of 100 for cattle (Dubey \& Jones, 2008; Lopes et al., 2013; Jokelainen et al., 2017) were chosen to maximize sensitivity and specificity of the test. The MAT is considered the most reliable, sensitive and specific test for the detection of antibodies to $T$. gondii in various hosts and does not require speciesspecific reagents (Desmonts \& Remington, 1980; Dubey \& Desmonts, 1987; Dubey et al., 1995).

\section{Data analysis}

Assuming a default 50\% seroprevalence value, a 95\% confidence level and a $10 \%$ absolute error, at least 97 animals from each species were calculated to include in this study. Exceptionally for cattle, the convenient sample of 48 animals corresponds to an absolute error of approximately 14\% (Thrusfield \& Christley, 2018). The chi-square or Fisher exact tests were used to compare seroprevalence values. Independent variables with significant difference between categories (probability $[p]$ value $<0.05$ ) were selected for multiple logistic regression analysis to identify independent risk factors for seropositivity by calculating odds ratios (OR) and their 95\% Cl (Petrie \& Watson, 2013). Statistical analyses were done with IBMS SPSS Statistics $26.0^{\circledR}$ software.

\section{Results}

Analysis of the 346 samples revealed an overall seroprevalence to T. gondii of $55.8 \%$ (193/346; 95\% Cl: 50.4-61.1). Antibodies to T. gondii were found in $13(27.1 \%)$ of the 48 cattle (Table 1): one had a titer of 100, four a titer of 400 , four a titer of 1600 and four a titer $\geq 6400$. Regarding sheep (Table 2), antibodies were found in $67(68.4 \%)$ of the 98 animals: a titer of 20 in three, a titer of 400 in one, a titer of 1600 in six and a titer of $\geq 6400$ in 57. Sixty-eight (70.1\%) out of the 97 goats were seropositive (Table 3): three had a titer of 400,11 a titer of 1600 and 53 a titer $\geq 6400$. Antibodies to $T$. gondii were found in 45 (43.7\%) of the 103 pigs (Table 4): eight had a titer of 20, 10 a titer of 400, 15 a titer of 1600 and 12 a titer $\geq 6400$. In pairwise comparison, statistically significant 
differences $(p<0.001)$ were found between sheep and pigs, sheep and cattle, goats and pigs, and goats and cattle.

Table 1. Seroprevalence of Toxoplasma gondii infection in cattle from São Tomé island according to gender, age group, breed and geographical area.

\begin{tabular}{|c|c|c|c|c|c|}
\hline & $\begin{array}{c}\text { Animals tested } \\
\text { (n) }\end{array}$ & $\begin{array}{c}\text { Relative } \\
\text { distribution (\%) }\end{array}$ & MAT-positive (n) & Prevalence (\%) & $95 \% \mathrm{Cl}$ \\
\hline \multicolumn{6}{|l|}{ Gender } \\
\hline Female & 45 & 93.8 & 11 & 24.4 & $12.9-39.5$ \\
\hline \multirow[t]{2}{*}{ Male } & 3 & 6.2 & 2 & 66.7 & 9.4-99.2 \\
\hline & & & & $p=0.174$ & \\
\hline \multicolumn{6}{|c|}{ Age group } \\
\hline Juvenile & 12 & 25.0 & 5 & 41.7 & $15.2-72.3$ \\
\hline \multirow[t]{2}{*}{ Adult } & 36 & 75.0 & 8 & 22.2 & $10.1-39.1$ \\
\hline & & & & $p=0.263$ & \\
\hline \multicolumn{6}{|l|}{ Breed } \\
\hline Mixed & 46 & 95.8 & 13 & 28.3 & $16.0-43.5$ \\
\hline \multirow[t]{2}{*}{ Defined } & 2 & 4.2 & 0 & 0.0 & $0.0-84.2$ \\
\hline & & & & $p=1.000$ & \\
\hline \multicolumn{6}{|c|}{$\begin{array}{c}\text { Geographical } \\
\text { area }\end{array}$} \\
\hline North & 30 & 62.5 & 3 & $10.0^{a}$ & $2.1-26.5$ \\
\hline Center & 4 & 8.3 & 0 & 0.0 & $0.0-60.2$ \\
\hline South & 14 & 29.2 & 10 & $\begin{array}{c}71.4^{\mathrm{a}} \\
p=\mathrm{NA}\end{array}$ & $41.9-91.6$ \\
\hline Total & 48 & 13.9 & 13 & 27.1 & $15.3-41.8$ \\
\hline
\end{tabular}

Bonferroni's correction (i.e. multiplying each $p$ value by 3 ) has been incorporated: a $p=0.003$ (only statistically significant differences are shown for pairwise comparisons of the geographical area category). $\mathrm{Cl}=$ confidence interval; MAT = modified agglutination test; $N A=$ not accounted (more than $20 \%$ of cells with expected counts less than 5 ).

Table 2. Seroprevalence of Toxoplasma gondii infection in sheep from São Tomé island according to gender, age group and geographical area.

\begin{tabular}{|c|c|c|c|c|c|}
\hline & $\begin{array}{c}\text { Animals tested } \\
\text { (n) }\end{array}$ & $\begin{array}{c}\text { Relative } \\
\text { distribution (\%) }\end{array}$ & MAT-positive (n) & Prevalence (\%) & $95 \% \mathrm{Cl}$ \\
\hline \multicolumn{6}{|l|}{ Gender } \\
\hline Female & 74 & 75.5 & 59 & 79.7 & $68.8-88.2$ \\
\hline \multirow[t]{2}{*}{ Male } & 24 & 24.5 & 8 & 33.3 & $15.6-55.3$ \\
\hline & & & & $p<0.001$ & \\
\hline \multicolumn{6}{|l|}{ Age group } \\
\hline Juvenile & 19 & 19.4 & 7 & 36.8 & 16.3-61.6 \\
\hline \multirow[t]{2}{*}{ Adult } & 79 & 80.6 & 60 & 75.9 & $65.0-84.9$ \\
\hline & & & & $p=0.003$ & \\
\hline \multicolumn{6}{|c|}{$\begin{array}{l}\text { Geographical } \\
\text { area }\end{array}$} \\
\hline North & 52 & 53.1 & 30 & $57.7^{a}$ & $43.2-1.3$ \\
\hline Center & 33 & 33.7 & 31 & $93.9^{a, b}$ & $79.8-99.3$ \\
\hline \multirow{2}{*}{ South } & 13 & 13.3 & 6 & $46.2^{b}$ & $19.2-74.9$ \\
\hline & & & & $p=0.001$ & \\
\hline Total & 98 & 28.3 & 67 & 68.4 & $58.2-77.4$ \\
\hline
\end{tabular}


Table 3. Seroprevalence of Toxoplasma gondii infection in goats from São Tomé island according to gender, age group, breed and geographical area.

\begin{tabular}{|c|c|c|c|c|c|}
\hline & $\begin{array}{l}\text { Animals tested } \\
\text { (n) }\end{array}$ & $\begin{array}{c}\text { Relative } \\
\text { distribution } \\
(\%)\end{array}$ & $\begin{array}{c}\text { MAT- } \\
\text { positive (n) }\end{array}$ & Prevalence (\%) & $95 \% \mathrm{Cl}$ \\
\hline \multicolumn{6}{|l|}{ Gender } \\
\hline Female & 67 & 69.1 & 51 & 76.1 & $64.1-85.7$ \\
\hline \multirow[t]{2}{*}{ Male } & 30 & 30.9 & 17 & 56.7 & $37.4-74.5$ \\
\hline & & & & $p=0.090$ & \\
\hline \multicolumn{6}{|l|}{ Age group } \\
\hline Juvenile & 23 & 23.7 & 8 & 34.8 & $16.4-57.3$ \\
\hline \multirow[t]{2}{*}{ Adult } & 74 & 76.3 & 60 & 81.1 & $70.3-89.2$ \\
\hline & & & & $p<0.001$ & \\
\hline \multicolumn{6}{|c|}{ Geographical area } \\
\hline North & 43 & 44.3 & 24 & $55.8^{a}$ & $39.9-70.9$ \\
\hline Center & 27 & 27.8 & 24 & $88.9^{a}$ & $70.8-97.6$ \\
\hline \multirow[t]{2}{*}{ South } & 27 & 27.8 & 20 & 74.1 & $53.7-88.9$ \\
\hline & & & & $p<0,001$ & \\
\hline Total & 97 & 29.8 & 68 & 70.1 & $60.0-79.0$ \\
\hline
\end{tabular}

Bonferroni's correction (i.e. multiplying each $p$ value by 3 ) has been incorporated: ${ }^{a} p=0.024$ (only statistically significant differences are shown for pairwise comparisons of the geographical area category). $\mathrm{Cl}=$ confidence interval; MAT = modified agglutination test.

Table 4. Seroprevalence of Toxoplasma gondii infection in pigs from São Tomé island according to gender, age group, breed and geographical area.

\begin{tabular}{|c|c|c|c|c|c|}
\hline & $\begin{array}{l}\text { Animals tested } \\
\text { (n) }\end{array}$ & $\begin{array}{c}\text { Relative } \\
\text { distribution (\%) }\end{array}$ & MAT-positive (n) & Prevalence (\%) & $95 \% \mathrm{Cl}$ \\
\hline \multicolumn{6}{|l|}{ Gender } \\
\hline Female & 50 & 48.5 & 21 & 42.0 & $28.2-56.8$ \\
\hline \multirow[t]{2}{*}{ Male } & 53 & 51.5 & 24 & 45.3 & $31.6-59.5$ \\
\hline & & & & $p=0.891$ & \\
\hline \multicolumn{6}{|l|}{ Age group } \\
\hline Juvenile & 25 & 24.3 & 15 & 60.0 & $38.7-78.9$ \\
\hline \multirow[t]{2}{*}{ Adult } & 78 & 75.7 & 30 & 38.5 & $27.7-50.2$ \\
\hline & & & & $p=0.097$ & \\
\hline \multicolumn{6}{|l|}{ Breed } \\
\hline Mixed & 90 & 87.4 & 37 & 41.1 & $30.8-52.0$ \\
\hline \multirow[t]{2}{*}{ Defined } & 13 & 12.6 & 8 & 61.5 & $31.6-86.1$ \\
\hline & & & & $p=0.276$ & \\
\hline \multicolumn{6}{|c|}{$\begin{array}{l}\text { Geographical } \\
\text { area }\end{array}$} \\
\hline North & 42 & 40.8 & 19 & 45.2 & $29.8-61.3$ \\
\hline Center & 20 & 19.4 & 10 & 50.0 & $27.2-72.8$ \\
\hline \multirow[t]{2}{*}{ South } & 41 & 39.8 & 16 & 39.0 & $24.2-55.5$ \\
\hline & & & & $p=0.695$ & \\
\hline Total & 103 & 29.8 & 45 & 43.7 & $33.9-53.8$ \\
\hline
\end{tabular}

$\mathrm{Cl}=$ confidence interval; MAT $=$ modified agglutination test.

Of the 193 seropositive animals, 6.7\% (13/193) were cattle, 34.7\% (67/193) were sheep, $35.2 \%$ (68/193) were goats and 23.3\% (45/193) were swine. Of these 193 seropositive animals, $65.3 \%(126 / 193)$ had a titer equal to or greater than 6400 . 
Regarding risk factors (Table 5), cattle from the south of the island had a significantly higher seroprevalence, with a 22.5 fold higher risk of positivity $(\mathrm{OR}=22.5 ; 95 \% \mathrm{Cl}$ : $4.3-$ 118.8). Sheep from the central geographical were 11.4 times more likely to be exposed $(\mathrm{OR}=11.4,95 \% \mathrm{Cl}: 2.5-52.6)$ than the northern sheep. The risk factors for $T$. gondii infection in goats, in descending order, were the adult age of animals $(\mathrm{OR}=6.7,95 \% \mathrm{Cl}$ : 2.3-19.6) and living in the central area ( $\mathrm{OR}=4.4,95 \% \mathrm{Cl}: 1.1-18.0)$. Gender and age group of sheep and age of goats were not confirmed as risk factors by multiple logistic regression.

Table 5. Identification of risk factors for Toxoplasma gondii infection in domestic animals from São Tomé island by multiple logistic regression.

\begin{tabular}{|c|c|c|c|}
\hline & Seroprevalence (\%) & OR & $95 \% \mathrm{Cl}$ \\
\hline \multicolumn{4}{|c|}{ Cattle $(n=48)$} \\
\hline \multicolumn{4}{|c|}{ Geographical area } \\
\hline North & 10.0 & 1 (Ref.) & \\
\hline Center & 0.0 & $0.0(p=0.999)$ & $0.0-0.0$ \\
\hline South & 71.4 & $22.5(p<0.001)$ & $4.3-118.8$ \\
\hline \multicolumn{4}{|c|}{ Sheep $(n=98)$} \\
\hline \multicolumn{4}{|c|}{ Geographical area } \\
\hline North & 57.7 & 1 (Ref.) & \\
\hline Center & 93.9 & $11.4(p=0.002)$ & $2.5-52.6$ \\
\hline South & 46.2 & $0.6(p=0.456)$ & $0.2-2.1$ \\
\hline \multicolumn{4}{|c|}{ Goats $(n=97)$} \\
\hline \multicolumn{4}{|l|}{ Age group } \\
\hline Juvenile & 34.8 & 1 (Ref.) & \\
\hline Adult & 81.1 & $6.7(p=0.001)$ & 2.3-19.6 \\
\hline \multicolumn{4}{|c|}{ Geographical area } \\
\hline North & 55.8 & 1 (Ref.) & \\
\hline Center & 88.9 & $4.4(p=0.040)$ & $1.1-18.0$ \\
\hline South & 74.1 & $2.3(p=0.158)$ & $0.7-7.2$ \\
\hline
\end{tabular}

$\mathrm{Cl}=$ confidence interval; OR = odds ratio; Ref. = reference category.

\section{Discussion}

The present study revealed an overall seroprevalence of $T$. gondii of $55.8 \%$, which supports the scenario of a considerable presence of sporulated oocysts as well as of infected intermediate hosts in the local environment. This is the first report on antibodies to $T$. gondii in cattle, sheep, goats and pigs from the DRSTP.

Goats had the highest recorded species seroprevalence $(70.1 \%)$ followed by sheep (68.4\%), pigs (43.7\%) and cattle (27.1\%). Literature generally indicates that the prevalence is higher in sheep than in goats (Hashemi-Fesharki, 1996; Sharif et al., 2007; Chikweto et al., 2011; Lopes et al., 2013), due to the selection of food. In fact, goats usually opt for taller leaves of shrubs, while sheep are pastoralists, which tend to eat grasses and clovers closer to the ground and, therefore, are more likely to contact with sporulated oocysts (Hamilton et al., 2014). The higher seroprevalence observed in small ruminants in the present work could also be due to the extensive system put into practice on the studied farms. Additionally, since the climatic conditions of the DRSTP are adequate for the sporulation of $T$. gondii oocysts, due to the hot and humid climate (Rahimi et al., 2015), it seems likely that exposure to water and food contaminated with T. gondii oocysts may be one of the most important factors associated with seropositivity to the protozoan in this country (Fan et al., 2012). 
Animals that feed on forage, such as cattle and small ruminants, are more susceptible to $T$. gondii due to contact with the soil, which may explain the higher seroprevalence observed in small ruminants compared with swine (Hamilton et al., 2014). Pigs in the present study, fed barley bark, breadfruit, bananas, jackfruit, taro and vegetables, had an above-expected seroprevalence of $43.7 \%$. A diet rich in raw vegetables and unwashed fruits may justify the higher prevalence observed in pigs in the present study, as well as in humans from the DRSTP in a previous report (Hung et al., 2007).

In the present work, the lowest seroprevalence was observed in cattle with $27.1 \%$. Although cattle can be infected with $T$. gondii, infection rarely results in clinical illness, including abortion (Innes, 1997). Attempts at isolation of $T$. gondii in experimentally- or naturally-infected cattle suggest that $T$. gondii does not persist for long in bovine tissues (Dubey, 1986, 2010), a circumstance which is unlike in sheep and humans (Innes, 1997). The reasons for such variation in host susceptibility to $T$. gondii are largely unknown. Although greater resistance to the parasite has been reported in cattle (Pita Gondim et al., 1999; Sharif et al., 2007), in the present study more than 25\% were seropositive.

There is a considerable debate concerning the role of beef in the epidemiology of T. gondii transmission to humans. The ingestion of beef has been epidemiologically linked to $T$. gondii infection in humans (Opsteegh et al., 2011) and, especially taking in consideration a country's existing eating habits, beef is not a negligible source of $T$. gondii infection for humans (Belluco et al., 2018); yet viable parasite has rarely been isolated from naturally infected cattle (Dubey, 2010). There is no agreement with respect to the cut-off titer for MAT for the detection of $T$. gondii antibodies in cattle. Using a cut-off titer of 100, as in the present study, T. gondii antibodies were found in $18.6 \%$ ( 743 of 3991) of cattle in Estonia (Jokelainen et al., 2017). Compared with the study from Estonia, the prevalence of $T$. gondii antibodies in Algeria was just 4.4\% (13 of 295; cut-off titer of 25) and only two animals were positive at a titer of 100 (Khames et al., 2018). In our study, T. gondii antibodies were found in $27.1 \%$ (13 of 48) and nine had a titer of 400 or higher. Although our sample size is small, this is the highest level of $T$. gondii antibodies reported in cattle worldwide (Dubey, 2010).

Additional data recorded in Nigeria revealed seroprevalence values of $6.7 \%$ in sheep, $4.6 \%$ in goats (Kamani et al., 2010) and $29.1 \%$ in pigs (Onyiche \& Ademola, 2015). For small ruminants, the different results obtained in northeastern Nigeria (Borno state) and the DRSTP may be due to differences in climate between these two geographical areas, since Borno is characterized by higher temperatures with a low relative humidity, which varies between $13 \%$ in the driest months and $70-80 \%$ in July and August (Kamani et al., 2010). In the DRSTP, the average temperature of the rainforest is around $26{ }^{\circ} \mathrm{C}$, with around $75 \%$ of air relative humidity in the highest altitude areas, where it rains even in the so-called dry season (Costa et al., 2014).

Compared with beef, pork is more likely to be infected with $T$. gondii, due to the high susceptibility of pigs to infection (Dubey, 2009; Hill \& Dubey, 2013). Tissue cysts may persist in pork over a long period of time, with $T$. gondii being identified as one of the most relevant biological risks in the context of meat inspection of pigs (EFSA, 2017). There is no testing of pork for T. gondii at slaughter anywhere in the world (Dorny et al., 2009; Blagojevic \& Antic, 2014; Herrero et al., 2016). In Italy, a literature data-based risk assessment model estimated that beef plays a more important role in human $T$. gondii infections than pork $(0.034 \%$ versus $0.019 \%$; excluding pork cured products), due to different cooking habits, even when cattle have a lower seroprevalence of the parasite (Belluco et al., 2018).

In goats, adult age group was identified as a risk factor for seropositivity to $T$. gondii, with adult goats 5.2 times more likely to be exposed than young animals. These results are probably related to oral transmission, with older animals being exposed to the infective forms of the protozoan for longer periods of time (Lundén et al., 1994). 
In the present work, seroprevalence according to geographical area was $45.5 \%$ in the north, $76.5 \%$ in the center and $54.7 \%$ in the south. Depending on the species studied, a higher seroprevalence was observed in sheep, goats and pigs from the central area, and in cattle from the southern one, with statistically significant differences detected in ruminants. Cattle from the south presented a 22.5 times higher risk of seropositivity than cattle living in the northern area. Likewise, sheep and goats from the central area were more likely to be seropositive in comparison with their northern counterparts. These figures may be a reflection of more visible poverty markers in the south of the country (Silva, 2014). Local potential sources of transmission include the quality of water supplied, hygienic management as well as contact with domestic cats (Tenter et al., 2000; Hung et al., 2007; Fan et al., 2012).

As stated earlier, there is limited data on T. gondii in humans in the DRSTP. Antibodies to T. gondii were reported in $21.5 \%$ of 121 pre-school children (Fan et al., 2006), in 63.1\% of 255 students attending primary school (Fan et al., 2012) and in $75.2 \%$ of 499 pregnant women (Hung et al., 2007), but these surveys are more than a decade old. The seroprevalence values observed are higher than the ones reported in countries geographically close to the DRSTP, such as Nigeria, with 32.0\% (Ohiolei \& Isaac, 2016), Gabon, with 56.0\% (Mickoto et al., 2010), and Cameroon, with 70.0\% (Njunda et al., 2011). In addition to the climatic variations, there are still sociocultural and dietary differences, which may explain such prevalence variations (Fan et al., 2006; Njunda et al., 2011; Rahimi et al., 2015; Wam et al., 2016). Access to food depends on family income. Meat and fish represent a large part of the total household expenditure, so that none of the families surveyed by Silva (2014) consumed beef because it is the most expensive and less available food in the DRSTP. Chevon and lamb are also of high cost and difficult access for the families of São Tomé. The most consumed product of animal origin is fish, followed by chicken and giant land snails (Silva, 2014). The DRSTP is often a tourist destination. In the present study, a high seroprevalence of $T$. gondii in food animals was found on São Tomé island. Risk groups should avoid eating undercooked meat, raw vegetables and unwashed fruits and also avoid direct contact with soil.

\section{Conclusions}

Seropositivity to $T$. gondii occurs in domestic animals of São Tomé and, although no clinical cases of toxoplasmosis have been reported in any animal species, this parasite should be considered in the list of differential diagnoses in reproductive, neurological or other pathological conditions. The source of $T$. gondii infection in the DRSTP may be associated with exposure to cat feces and contact with soil or water contaminated by oocysts, leading to a higher probability of parasite ingestion in raw foods such as vegetables and fruits and contaminated water or soil. This is the first study on the prevalence of antibodies to T. gondii in domestic animals of the DRSTP. The results will be of interest to biologists, parasitologists, and public health workers.

\section{Acknowledgements}

The authors would like to thank Mr. Joseldo Andrade, Mrs. Fátima Vera Cruz and Dr. Alzira Garcês, Central Laboratory for Veterinary Diagnosis of São Tomé, for their assistance regarding field work, and Eng. Teresa Coutinho, UTAD, for her assistance with laboratory work. This study was funded by project UID/CVT/00772/2019, supported by the Portuguese Science and Technology Foundation (FCT). 


\section{References}

Belluco S, Patuzzi I, Ricci A. Bovine meat versus pork in Toxoplasma gondii transmission in Italy: a quantitative risk assessment model. Int J Food Microbiol 2018; 269: 1-11. http://dx.doi.org/10.1016/j.ijfoodmicro.2017.12.026. PMid:29358131.

Blagojevic B, Antic D. Assessment of potential contribution of official meat inspection and abattoir process hygiene to biological safety assurance of final beef and pork carcasses. Food Control 2014; 36(1): 174-182. http://dx.doi.org/10.1016/j.foodcont.2013.08.018.

Chikweto A, Kumthekar S, Tiwari K, Nyack B, Deokar MS, Stratton G, et al. Seroprevalence of Toxoplasma gondii in pigs, sheep, goats, and cattle from Grenada and Carriacou, West Indies. J Parasitol 2011; 97(5): 950-951. http://dx.doi.org/10.1645/GE-2811.1. PMid:21506801.

Costa R, Costa C, Mira FB, Breda Z. Turismo nos países Lusófonos: conhecimentos, estratégia e territórios. Lisboa: Escolar Editora; 2014.

DeFeo ML, Dubey JP, Mather TN, Rhodes RC 3rd. Epidemiologic investigation of seroprevalence of antibodies to Toxoplasma gondii in cats and rodents. Am J Vet Res 2002; 63(12): 1714-1717. http://dx.doi.org/10.2460/ajvr.2002.63.1714. PMid:12492287.

Desmonts G, Remington JS. Direct agglutination test for diagnosis of Toxoplasma infection: method for increasing sensitivity and specificity. J Clin Microbiol 1980; 11(6): 562-568. PMid:7000807.

Dorny P, Praet N, Deckers N, Gabriel S. Emerging food-borne parasites. Vet Parasito/ 2009; 163(3): 196-206. http://dx.doi.org/10.1016/j.vetpar.2009.05.026. PMid:19559535.

Dubey JP. A review of toxoplasmosis in cattle. Vet Parasitol 1986; 22(3-4): 177-202. http://dx.doi.org/10.1016/0304-4017(86)90106-8. PMid:3551316.

Dubey JP. Toxoplasmosis in pigs: the last 20 years. Vet Parasitol 2009; 164(2-4): 89-103. http://dx.doi.org/10.1016/j.vetpar.2009.05.018. PMid:19559531.

Dubey JP. Toxoplasmosis of animals and humans. 2nd ed. Boca Raton: CRC Press; 2010.

Dubey JP, Desmonts G. Serological responses of equids fed Toxoplasma gondii oocysts. Equine Vet J 1987; 19(4): 337-339. http://dx.doi.org/10.1111/j.2042-3306.1987.tb01426.x. PMid:3622463.

Dubey JP, Jones JL. Toxoplasma gondii infection in humans and animals in the United States. Int J Parasitol 2008; 38(11): 1257-1278. http://dx.doi.org/10.1016/j.ijpara.2008.03.007. PMid:18508057.

Dubey JP, Thulliez P, Weigel RM, Andrews CD, Lind P, Powell EC. Sensitivity and specificity of various serologic tests for detection of Toxoplasma gondii infection in naturally infected sows. Am J Vet Res 1995; 56(8): 1030-1036. PMid:8533974.

European Food Safety Authority - EFSA. European Centre for Disease Prevention and Control ECDC. The European Union summary report on trends and sources of zoonoses, zoonotic agents and food-borne outbreaks in 2016. EFSA J 2017; 15(12): 5077.

Fan CK, Hung CC, Su KE, Sung FC, Chiou HY, Gil V, et al. Seroprevalence of Toxoplasma gondii infection among pre-schoolchildren aged 1-5 years in the Democratic Republic of Sao Tome and Principe, Western Africa. Trans R Soc Trop Med Hyg 2006; 100(5): 446-449. http://dx.doi.org/10.1016/j.trstmh.2005.07.013. PMid:16260015.

Fan CK, Lee LW, Liao CW, Huang YC, Lee YL, Chang YT, et al. Toxoplasma gondii infection: relationship between seroprevalence and risk factors among primary schoolchildren in the capital areas of Democratic Republic of São Tomé and Príncipe, West Africa. Parasit Vectors 2012; 5(1): 141. http://dx.doi.org/10.1186/1756-3305-5-141. PMid:22794195.

Halonen SK, Weiss LM. Toxoplasmosis. Handb Clin Neurol 2013; 114: 125-145. http://dx.doi.org/10.1016/B978-0-444-53490-3.00008-X. PMid:23829904.

Hamilton CM, Katzer F, Innes EA, Kelly PJ. Seroprevalence of Toxoplasma gondii in small ruminants from four Caribbean islands. Parasit Vectors 2014; 7(1): 449. http://dx.doi.org/10.1186/17563305-7-449. PMid:25249175.

Hashemi-Fesharki R. Seroprevalence of Toxoplasma gondii in cattle, sheep and goats in Iran. Vet Parasitol 1996; 61(1-2): 1-3. http://dx.doi.org/10.1016/0304-4017(95)00818-7. PMid:8750677.

Herrero L, Gracia MJ, Pérez-Arquillué C, Lázaro R, Herrera M, Herrera A, et al. Toxoplasma gondii: pig seroprevalence, associated risk factors and viability in fresh pork meat. Vet Parasitol 2016; 224: 52-59. http://dx.doi.org/10.1016/j.vetpar.2016.05.010. PMid:27270390. 
Hill DE, Dubey JP. Toxoplasma gondii prevalence in farm animals in the United States. Int J Parasitol 2013; 43(2): 107-113. http://dx.doi.org/10.1016/j.ijpara.2012.09.012. PMid:23201235.

Hung CC, Fan CK, Su KE, Sung FC, Chiou HY, Gil V, et al. Serological screening and toxoplasmosis exposure factors among pregnant women in the Democratic Republic of Sao Tome and Principe. Trans R Soc Trop Med Hyg 2007; 101(2): 134-139. http://dx.doi.org/10.1016/j.trstmh.2006.04.012. PMid:17113117.

Innes EA. Toxoplasmosis: comparative species susceptibility and host immune response. Comp Immunol Microbiol Infect Dis 1997; 20(2): 131-138. http://dx.doi.org/10.1016/s01479571(96)00038-0. PMid:9208198.

Instituto Nacional de Estatísticas - INE [online]. Republica Democrática de São Tomé e Príncipe: INE; 2017 [cited 2019 July 31]. Available from: https://www.ine.st/

Jokelainen P, Tagel M, Mõtus K, Viltrop A, Lassen B. Toxoplasma gondii seroprevalence in dairy and beef cattle: large-scale epidemiological study in Estonia. Vet Parasitol 2017; 236: 137-143. http://dx.doi.org/10.1016/j.vetpar.2017.02.014. PMid:28288757.

Kamani J, Mani AU, Egwu GO. Seroprevalence of Toxoplasma gondii infection in domestic sheep and goats in Borno state, Nigeria. Trop Anim Health Prod 2010; 42(4): 793-797. http://dx.doi.org/10.1007/s11250-009-9488-3. PMid:19882227.

Khames M, Yekkour F, Fernández-Rubio C, Aubert D, Nguewa P, Villena I. Serological survey of cattle toxoplasmosis in Medea, Algeria. Vet Parasitol Reg Stud Rep 2018; 12: 89-90. http://dx.doi.org/10.1016/j.vprsr.2018.02.009. PMid:31014815.

Lopes AP, Dubey JP, Neto F, Rodrigues A, Martins T, Rodrigues M, et al. Seroprevalence of Toxoplasma gondii infection in cattle, sheep, goats and pigs from the North of Portugal for human consumption. Vet Parasitol 2013; 193(1-3): 266-269. http://dx.doi.org/10.1016/j.vetpar.2012.12.001. PMid:23290614.

Lundén A, Näsholm A, Uggla A. Long-term study of Toxoplasma gondii infection in a Swedish sheep flock. Acta Vet Scand 1994; 35(3): 273-281. PMid:7847196.

Mickoto RM, Akue JP, Bisvigou U, Tsonga SM, Nkoghe D. Étude sérologique de la toxoplasmose chez les femmes enceintes de Franceville, Gabon. Bull Soc Pathol Exot 2010; 103(1): 41-43. http://dx.doi.org/10.1007/s13149-009-0031-6. PMid:20084487.

Njunda AL, Assob JC, Nsagha DS, Kamga HL, Nde PF, Yugah VC. Seroprevalence of Toxoplasma gondii infection among pregnant women in Cameroon.J Public Health Afr 2011; 2(2): e24. http://dx.doi.org/10.4081/jphia.2011.e24. PMid:28299065.

Ohiolei JA, Isaac C. Toxoplasmosis in Nigeria: the story so far (1950-2016): a review. Folia Parasitol (Praha) 2016; 63(1): 1-9. http://dx.doi.org/10.14411/fp.2016.030.

Onyiche TE, Ademola IO. Seroprevalence of anti-Toxoplasma gondii antibodies in cattle and pigs in Ibadan, Nigeria. J Parasit Dis 2015; 39(2): 309-314. http://dx.doi.org/10.1007/s12639-013-0350-1. PMid:26064025.

Opsteegh M, Prickaerts S, Frankena K, Evers EG. A quantitative microbial risk assessment for meatborne Toxoplasma gondii infection in The Netherlands. Int J Food Microbiol 2011; 150(2-3): 103-114. http://dx.doi.org/10.1016/j.ijfoodmicro.2011.07.022. PMid:21864927.

Petrie A, Watson P. Statistics for veterinary and animal science. 3rd ed. Chichester: Wiley-Blackwell; 2013.

Pita Gondim LF, Barbosa HV Jr, Ribeiro CHA Fo, Saeki H. Serological survey of antibodies to Toxoplasma gondii in goats, sheep, cattle and water buffaloes in Bahia State, Brazil. Vet Parasitol 1999; 82(4): 273-276. http://dx.doi.org/10.1016/S0304-4017(99)00033-3. PMid:10384902.

Rahimi MT, Daryani A, Sarvi S, Shokri A, Ahmadpour E, Teshnizi SH, et al. Cats and Toxoplasma gondii: a systematic review and meta-analysis in Iran. Onderstepoort J Vet Res 2015; 82(1): e1-e10. http://dx.doi.org/10.4102/ojvr.v82i1.823. PMid:26017063.

Sharif M, Gholami S, Ziaei H, Daryani A, Laktarashi B, Ziapour SP, et al. Seroprevalence of Toxoplasma gondii in cattle, sheep and goats slaughtered for food in Mazandaran province, Iran, during 2005. Vet J 2007; 174(2): 422-424. http://dx.doi.org/10.1016/j.tvjl.2006.07.004. PMid:16919980.

Silva C. Segurança alimentar em São Tomé e Príncipe: estudo de caso dos distritos de Água-Grande e MéZóchi [dissertation]. Lisbon: Instituto Superior de Agronomia, Universidade de Lisboa; 2014. 
Sousa S, Thompson G, Silva E, Freire L, Lopes D, Correia da Costa JM, et al. Determination of the more adequate modified agglutination test cut-off for serodiagnosis of Toxoplasma gondii infection in sheep. Zoonoses Public Health 2009; 56(5): 252-256. http://dx.doi.org/10.1111/j.18632378.2008.01187.x. PMid:19068071.

Tenter AM, Heckeroth AR, Weiss LM. Toxoplasma gondii: from animals to humans. Int J Parasitol 2000; 30(12-13): 1217-1258. http://dx.doi.org/10.1016/S0020-7519(00)00124-7. PMid:11113252.

Thrusfield M, Christley R. Veterinary epidemiology. 4th ed. Hoboken: Wiley-Blackwell; 2018. http://dx.doi.org/10.1002/9781118280249.

Wam EC, Sama LF, Ali IM, Ebile WA, Aghangu LA, Tume CB. Seroprevalence of Toxoplasma gondii IgG and IgM antibodies and associated risk factors in women of child-bearing age in Njinikom, NW Cameroon. BMC Res Notes 2016; 9(1): 406. http://dx.doi.org/10.1186/s13104-016-2206-0. PMid:27528009.

Wikipedia [online]. 2017 [cited 2019 July 31]. Available from: www.wikipedia.org 